UDK 659.3:343.85

https://doi.org/10.18485/fb_ic4hs.2018.20

\title{
THE ROLE OF MEDIA IN VIOLENCE PREVENTION
}

\begin{abstract}
Aleksandra ILIĆ*
Abstract: Violence has always been one of the topics that attracts great public attention. It is visible today in everyday news reports on crime with violence as dominant issue. Also, violence is the common topic of films and television series. The conclusion that can be derived from it is that violence is everywhere around us. On the other hand, it seems that society is very sensitive when it comes to some forms of violence acts. In that sense the role of media in violence prevention can be understood as both positive and negative. Media are the most powerful source of information and have great influence on public understanding of the problem of violence. Public reaction to violence depends usually on media construction of it. The problem with media construction of violence is its deviation from reality to a greater or lesser extent. Media image of violence is a combination of real information and construction and is usually based on sensationalism. The positive side of media's focus on violence is that they inform the public on the dimensions and characteristics of some forms of violence, which is one of the important aspects of its prevention. Also, a better understanding of the crime is crucial in its suppression. This is especially true when it comes to domestic violence, paedophilia, rape or juvenile delinquency. On the other hand, very often these mentioned crimes are presented in the media in an inadequate way which causes moral panic reaction with all its negative consequences as an irrational fear of crime or labelling some groups of people as common perpetrators. All of it could hamper the efforts of different subjects, especially law enforcement agencies in dealing with violence. In that sense, the conclusion is that only true and unbiased media reporting of violence could make some positive changes in its prevention.
\end{abstract}

Keywords: media, construction, violent crime, prevention, moral panic;

\section{INTRODUCTION}

Given the current advent and development of mass media, the influence of the media as a source of knowledge about crime is enormous. A substantial part of social knowledge is gained symbolically from the media, and some of the authors are concerned over media

\footnotetext{
* Associate Professor, PhD,University of Belgrade Faculty of Security Studies, aleksandra.ilic@fb.bg.ac.rs
} 
content (Surette, 2007:34). That this concern is not unreasonable is indicated by some of the latest criminological research, according to which four fifths (80\%) of citizens' views on criminality in general, as well as on some of its types, are based on the information obtained through the media (Ignjatović, 2009:176). We live at the time when the media have taken over a guarding role from the family, replaced the churches as headquarters of cultural values, instead of schools they have started to educate children and youth and to set priority national goals (Ott \& Mack, 2010:11). It is therefore necessary to pay special attention to the analysis of the role of the media as a source of knowledge about criminality and their contribution to the creation of a social construction of crime.

Certain forms of crime instinctively attract people and keep their attention for longer time, while other topics, despite being a bigger problem, arouse much less interest. When choosing news, the media also take into account this circumstance, which means it is more effective to draw public attention to 'appropriate' topics such as a violent crime, which causes fear among citizens, and therefore they do not try to do the same with some forms of property crime in relation to which there is greater tolerance.

The choice of crime news is often related to discouraging public attention from real social issues such as unemployment, poverty, economic crisis or other 'burning' issues. In the background of this concealment, there are, by the rule, the efforts of certain political groups to maintain social peace and to achieve the narrow interests of those who possess power. In other words, the control of information in the media represents the very basis of political power. In this sense, the ability to form a convincing discourse for public consumption is vital for sustaining that power (Prajs, 2011:552).

\section{MEDIA CONSTRUCTION OF VIOLENCE}

As a society we are fascinated by the crime. The stories of crime are ubiquitous not only in movies, newspapers, books, magazines, articles, on the Internet, television, radio, but also in everyday communication. In other words, crime is a central point of discussion (Muraskin \& Domash, 2007:13). This fascination is especially evident when it comes to violent crime. Through media coverage of violence, people can experience extreme situations without actually being part of it. In that way people have access to those emotional aspects that are not usually part of everyday life (Svensen, 2008:95).

Violent events meet the need of media to improve readership of newspapers or TV channel ratings. Almost daily, the media present the data on the chances of a woman or child being victims of various forms of violence, and interviews with various experts, psychologists, pedagogues, etc. who provide alarming information on the epidemic proportions of these problems, which is accepted without reserve by the public. It is a general conclusion that all forms of violence are in a constant growth despite the fact that official statistics say the opposite. Important aspects of media construction of crimes are symbolic crimes which usually emphasise the worst, most heinous types of crimes and the most innocent victims (Surette, 2003:44).

It can be said that violent crime has the 'ability' to attract great public attention, which leads to the creation of moral panic. No other form of criminal activity is so much 
connected with the issue of morality and attacks on some of the basic values of every modern society (Kosloski, 2010:16). All forms of manifestation of moral panic in relation to violence and stereotypes that are inherent in them have their roots in the stereotype of a bloodthirsty criminal or predator, where such super-predatory discourse distorts reality (Moriearty, 2010:852).

The crimes that dominate public consciousness and policy debates, whose actors are predatory criminals, are not common crimes, but the rarest ones. Our desire to understand and control these incomprehensible and uncontrollable criminals is long-standing and is reflected in much of classical literature. However, the modern mass media have raised the spectre of the predatory criminal from a minor character to a common, ever-present image (Surette, 1994:131,132).

The most common image of a predatory criminal is that he is different from all other 'normal' people. His criminality stems from individual problems. He freely chooses his criminality and is not bound or restrained in any way by normal social rules and values. The predator is always a stranger who suddenly appears in order to commit a crime whereby the choice of the victim is generally not subject to some specific criteria. Predatory victims are in most cases random, helpless and innocent (Surette, 1994: 134,135).

\section{MEDIA AND SPECIFIC FORMS OF VIOLENT CRIME}

When it comes to specific forms of violent crime, moral panic usually occurs in connection with domestic violence, rape, paedophilia and violent behaviour of young people. Often the media explanation of these forms of violence emphasises what is characteristic of predatory crimes, both in terms of the basic feature of the perpetrators and the typical profile of the victims.

While moral panic is basically a negative consequence of excessive and sensational media coverage of a subject, media coverage of violence can have a positive effect. Violence generally, as well as all its special forms of manifestation, are negative phenomena which must be suppressed both on a preventive and repressive plan. In both cases, the media play an important role, since in order to achieve mentioned effects, it is necessary to provide a consensus in the society. In other words, through continuous and adequate reporting on the problem of violence, public awareness can be raised.

In this sense, the positive effects of the public and thus the media dealing with the phenomenon of domestic violence are the corresponding changes in the criminal legislation of the Republic of Serbia that happened more than sixteen years ago. Namely, in March 2002, the amendments1 to the then valid Criminal Code2 (Article 118a) introduced a relatively new criminal offense of domestic violence that did not exist under

\footnotetext{
${ }^{1}$ Law on Amendments and Additions to the Criminal Code of the Republic of Serbia ("Official Gazette of the Republic of Serbia", No. 10/02).

${ }^{2}$ Criminal Code of the Republic of Serbia ("Official Gazette of the Republic of Serbia", No. 26/77, 28/77 corr., 43/77 - corr., 20/79, 24/84, 39/86, 51/87, 6/89 , 42/89 and 21/90 and "Official Gazette of the RS", No. 16/90, 26/91 - decision of the CCJ No. 197/87, 75/91 - decision of the CC RS No. 58/91, 9/92, 49/92, 51/992, 23/93, 67/93, 47/94, 17/95, 44/98, 10/02, 11/02 - corr., 80/02 other law, 39/03 and 67/03).
} 
that name, although various forms of its manifestation were sanctioned earlier in other criminal offenses (murder, serious bodily injury, rape, etc.) (Stojanović \&Delić.2013:108). By introducing the mentioned incrimination, the phenomenon of domestic violence has become more visible because the sphere of marriage and family relations has always been treated as a predominantly private sphere of individuals, any interventions being extremely rare, and so the cases of violent behaviour within it have been taboo topic.

After complete silence regarding the issue of domestic violence, a period of intense and constant engagement with this topic in our country started almost two decades ago. However, reporting on domestic violence became at one point overstated. The public began to get the impression that domestic violence is a relatively new phenomenon, i.e. that it had not existed before or that it had been present in a much lesser extent. Over time, ordinary concern has become a moral panic with all its consequences.

The exaggeration in media coverage of the scale and characteristics of domestic violence can cause great harm to the institutions of marriage and family. In this respect, it seems that for the future of family and marriage as institutions the view that these spheres represent sites of (largely masculine) violence, sexual abuse and murder is particularly dangerous (Jewkes, 2004:121). In this way, science is used to reinforce prejudices and stereotypes instead of combating them. Objectivity and moderation are the keys to the proper understanding of each problem, and in this, the media continue to play an important role.

On the other hand, rape is one more criminal offense which attracts great public and media attention. Boundaries of criminal protection in the Republic of Serbia in this area have spread over the past thirteen years, including forms that had not been sanctioned before, inter alia, rape in marriage and rape of male victim which are present in current Criminal Code. ${ }^{3}$ All of these changes are also the result of a long-standing public campaign with the aim of raising public awareness of this phenomenon.

However, like domestic violence, the media image of rape is a construction that has been created on many myths and misconceptions. To many people, and the media, rape is largely about sexual gratification (Howitt, 1998:91). Although it is implied that this gratification also involves the manifestation of aggression, the emphasis is still put on the sexual plane.

Numerous studies have shown a significant discrepancy between the media construction of the typical rapist and the reality that can be determined by insight into the official statistical data. Media claim that danger exists not from ordinary men but immensely troubled and pathological individuals (Howitt, 1998:121). The myth of a rapist as an abnormal person can also be found in the statements of government officials, which is probably the key contribution in the creation of moral panic (Burchfield et. al., 2014:109).

The image of women victims of rape is often distorted and is the result of a replaced discourse that often emphasises the contribution of women to the commission of rape, but ignores the fact that violence is being used against her and that the perpetrator should be responsible regardless of the circumstances of the particular case. The stigmatisation of

\footnotetext{
${ }^{3}$ Criminal Code of the Republic of Serbia („Official Gazette of the Republic of Serbia", No. 85/05, 88/05 - corr., 107/05 - corr., 72/09, 111/09, 121/12, 104/13 and 108/14).
} 
women through the dominant media coverage of victims of sexual offenses in general, and especially victims of rape, would disappear only if those victims were taken seriously without hiding behind the stories of their innocence and virginity (Boyle, 2005:29).

The children as victims of violent crimes are always in the focus of media. Apart from domestic violence, children are at the heart of the media interest and when it comes to paedophilia. Philip Jenkins argues that any criminal offence that involves children as victims or perpetrators, and especially when it deviates from the existing moral consensus, has the greatest media attention (Jewkes, 2004: 56, 57).

The dominant media discourse on paedophilia is that unknown persons represent the greatest threat to children. This discourse supports the stereotypical presentation of a typical pedophile ignoring the reality that is different. Typical pedophiles in the media construction are rather grubby, inadequate loners, a misfits who are not 'one of us' (Jewkes, 2004:96). It is true that child abusers are mostly men aged between 20 and 30, in $60-80 \%$ of cases involving persons who are acquaintances or even relatives of the victim. The estimates of the dark number of violence against children range from 1:6 to 1:20 (Ignjatović \& Simeunović-Patić, 2011:67), and most of them are the cases where the perpetrator is known to the victim. In this sense, one of the myths regarding paedophilia is about the home as a safe area, due to which the public ignores the problem of sexual abuse of children in the private sphere.

The consequences of misconceptions about paedophilia can be very serious. The price that the whole society pays is high: the actual perpetrators can be overlooked and even avoid justice; wrongful arrests can be made; the police can lose valuable time; the public can behave vengeful; trials may be questioned for misrepresentation; and very serious damage can occur in affected families and related communities (Wykes \& Welsh, 2009:21). Nevertheless, the highest price that can be paid is the non-recognition of the most common cases of sexual abuse of children or their late recognition when nothing more can be done.

Finally, it should be mentioned that violent behaviour of young people is always interesting to the media. It is interesting that the excessive public reaction is caused mainly because of the behaviour of young people who do not deserve such attention. These are usually those acts that can be attributed to juvenile delinquency in a wider sense, such as the difficulties in education and petty offences of young people, which appears as a typical "youth rebellion against the adult world" (Ignjatović, 2015:15).

Continuous and constant presentation of the youth in a negative sense has significantly contributed to the creation of an atmosphere of fear regarding the aggressiveness of young people and it usually reaches culmination when a minor commits some serious crime (murder, robbery, etc.). However, these most serious crimes of juveniles are not the most common forms of the manifestation of juvenile delinquency that appear on the daily basis in courts (Wykes \& Welsh, 2009:134). However, dramatic and excessive reporting of juvenile offenses often leads to more severe punishment (Shepherd, 1999:688). From the one definitely difficult situation, but very rare, the media create an entire show that should present young people only in a negative context. 


\section{CONCLUSION}

The positive and negative roles of the media in the context of violence are constantly intertwined. Without the media, it is almost impossible to accomplish any important social task, and in that sense, concrete steps must be taken to prevent violence. The analysis of the media image of violence in general and its specific forms of manifestation provides important information about the public's attitude. On the other hand, scientific dealing with the dimensions and characteristics of various forms of violence indicates the misconceptions and myths that are part of that media picture. To this end, it is necessary to understand the undertaking of activities whose aim is the prevention of violence. Without breaking the misconceptions and demystification of the phenomenon of violence, there is no effective prevention. That is why it is important that media reporting is complete and truthful.

Media construction of the reality of a crime and moral panic as its consequence will not disappear, but they must be controlled if we want the media to be allies in the prevention of violence. All important social actors must be engaged for this purpose, representatives of formal social control, subjects that are part of civil society and the academic community, which must be more actively involved in the realisation of this idea.

\section{REFERENCES}

Boyle, K. (2005). Media and Violence: Gendering the Debates. London: Sage Publications.

Burchfield, K., Sample, L. L. \& Lytle, R. (2014). Public Interest in Sex Offenders: A Perpetual Panic? Criminology, Criminal Justice Law, \& Society, 15(3), 96-117.

Criminal Code of the Republic of Serbia ("Official Gazette of the Republic of Serbia", No. 26/77, 28/77 - corr., 43/77 - corr., 20/79, 24/84, 39/86, 51/87, 6/89 , 42/89 and 21/90 and "Official Gazette of the RS", No. 16/90, 26/91 - decision of the CCJ No. 197/87, 75/91 - decision of the CC RS No. 58/91, 9/92, 49/92, 51/992, 23/93, 67/93, 47/94, 17/95, 44/98, 10/02, 11/02 - corr., 80/02 other law, 39/03 and $67 / 03)$.

Criminal Code of the Republic of Serbia („Official Gazette of the Republic of Serbia", No. 85/05, 88/05 - corr., 107/05 - corr., 72/09, 111/09, 121/12, 104/13 and 108/14).

Howitt, D. (1998). Crime, the Media and the Law. Chichester: John Wiley \& Sons.

Ignjatović, Đ. (2009). Metodologija istraživanja kriminaliteta. Beograd: Pravni fakultet u Beogradu.

Ignjatović, Đ. (2015). Kriminologija. Beograd: Pravni fakultet u Beogradu.

Ignjatović, Đ. \& Simeunović-Patić, Đ. (2011). Viktimologija. Beograd: Pravni fakultet u Beogradu.

Jewkes, Y. (2004). Media and Crime. London: Sage Publications.

Kosloski, A. (2010). Violent Offenders. In: Transnational Criminology Manual, 2, (pp. 3147). Nijmegen: Wolf Legal Publishers.

Law on Amendments and Additions to the Criminal Code of the Republic of Serbia ("Official Gazette of the Republic of Serbia", No. 10/02). 
Moriearty, L. P. (2010). Framing Justice: Media, Bias, and Legal Decisionmaking. Maryland Law Review, 69, 849-909.

Muraskin, R. \& Domash, S. F. (2007). Crime and the Media: headlines versus reality. New Jersey: Pearson Prentice Hall.

Ott, B. L. \& Mack, R. L. (2010). Critical media studies: an introduction. London: WileyBlackwell.

Prajs, S. (2011). Izučavanje medija (Media Studies, translator: Kolović, V.). Beograd: CLIO.

Roberts, V. J. (1992). Public Opinion, Crime and Criminal Justice. Crime and Justice, 99180.

Shepherd, R. E. Jr. (1999). Film at Eleven: The News Media and Juvenile Crime, Quarterly Law Review, 18, 687-700.

Stojanović, Z. \& Delić, N. (2013). Krivično pravo-posebni deo. Beograd: Pravni fakultet Univerziteta u Beogradu.

Surette, R. (1994). Predator Criminals as Media Icons. In: Media, Process, and the Social Construction of Crime: Studies in Newsmaking Criminology, (pp. 131-158). New York: Garland Publishing.

Surette, R. (2003). The Media, the Public, the Criminal Justice Policy, Journal of the Institute of Justice \& International Studies, 39-52.

Surette, R. (2007). Media, Crime and Criminal Justice: Images, Realities and Pollicies. Belmont: Thomson Wadsworth.

Svensen, L. Fr. H. (2008). Filozofija straha (Frykt, translator Rajić, Lj.). Beograd: Geopoetika.

Wykes, M. \& Welsh, K. (2009). Violence, Gender \& Justice. London: Sage Publications. 